\title{
PERFORMANCE OF A FISHERY HARVESTING DIFFERENT MINIMUM SHRIMP SIZES IN THE ARAFURA SEA
}

\author{
Purwanto \\ Research Center for Fisheries Management and Conservation \\ Received August 7-2012; Received in revised form December 19-2012; Accepted December 20-2012 \\ E-mail : purwanto.pp@gmail.com
}

\begin{abstract}
Avoiding overfishing and ensuring the sustainability of the shrimp stock in the Arafura Sea are of prime importance for fishery management. Exploited shrimp stock consists of several cohorts, and grows considerably with age. When the shrimps are caught before the cohort has had the opportunity to achieve its optimum biomass level, the fishery will lose much of the potential benefit that could be achieved by catching them in the near future. Therefore, a bio-economic approach was developed, on the basis of the length-based Thompson \& Bell model, to evaluate the impact of harvesting different size of shrimps on fishery performance. The result of analysis shows that the fishery achieved the optimal total profit when the shrimp size at first-capture and fishing mortality were $29 \mathrm{~mm} C L$ and 0.50 , respectively. The total profit to the fishery would be sub-optimal when the shrimp size at-first-capture was smaller or larger than the optimal size. Further, it was more economical to harvest shrimps at the larger size and higher fishing mortality, and resulting in higher total profit, when natural mortality decreased.
\end{abstract}

KEYWORDS: Bio-economic, Thompson \& Bell model, shrimp fishery, optimum size at first capture.

\section{INTRODUCTION}

Arafura Sea is one of the most productive fishing grounds for shrimp fishery in Indonesia. This fishing ground is highly productive (Bailey et al., 1987), as this area is shrimp habitat that is regularly enriched by nutrient rich upwelling and nutrient inputs from river flow, and supported by nursery sites in the coastal area. The Arafura Sea is one of the few areas within the Indonesian EEZ where nutrient rich upwelling occurs. In the Banda and Arafura Seas, upwelling develops under the influence of the southeast monsoon (Wyrtki, 1961). The upwelling increases nutrient (Wetsteyn et al., 1990), organic carbon (Cadee, 1988), which in turn increases phytoplankton biomass. Then, this increases oxygen production (Tijssen et al., 1990), and zooplakton abundance (Baars et al., 1990). Meanwhile, water mass flowing in the large rivers carries nutrient from the dense forest in the hinterland of Papua into the Arafura Sea during rainy season. Nutrient is also transported to the Arafura Sea from the dense mangrove area along the west coast of Papua (Sadhotomo et al., 2003). However, High primary productivity in the Arafura Sea during the southeast monsoon were not due to river runoff but by vertical mixing with the nutrient rich deeper water (Wetsteyn et al., 1990). The mangrove area also contributes to the productivity of the fishing ground in the Arafura Sea from its function as nursery site of shrimps. The association of post-larvae and juvenile of shrimps with mangroves are reported e.g. by
Robertson \& Duke (1987), Vance et al. (1990, 1996, 2002), Primavera $(1997,1998)$, and Nagelkerken et al. (2008).

Based on the estimates of potential yield of Indonesian marine fisheries (Indonesia's Ministerial Decree of Marine Affairs and Fisheries no. 45 year 2011), the shrimp stock in the Arafura Sea can sustainably produce about $45 \%$ of the total potential yield of shrimps of Indonesia. The trawlable area for shrimp fishing in the Arafura Sea was about 74,000 $\mathrm{km}^{2}$, for water depths ranging from $10-50 \mathrm{~m}$ (Naamin, 1984; Sadhotomo et al., 2003). The commercial fishing operation targeting shrimps in the Arafura Sea was started in the early 1970 s after the findings rich shrimp stocks and the introduction of the double rigged shrimp trawl in that fishing area during the late 1960s, prompted by strong international demand for shrimp (Bailey et al., 1987). Trawl became one of the main fishing gears in Indonesia as it was the most productive fishing gear for demersal fisheries.

The fishing capacity of trawl fleet in the Arafura Sea was continuously developed. Fishing pressure to the shrimp stock further increased with the operation of fish trawlers in Arafura Sea since mid1980. The development of fishing fleet targeting shrimp stock has substantially reduced the abundance of demersal stocks in this area. Naamin, (1984), Badrudin et al. (2002) estimated optimal effort required to produce optimal yield from the utilisation of the shrimp 
stock in the Arafura Sea. Meanwhile, Widodo et al. (2001) evaluated the development of demersal fishery, including shrimp fishery, in the Arafura Sea and concluded that the stocks of demersal fishes and shrimps in this area were over-exploited. The overexploitation of shrimp stock in the Arafura Sea has threatened sustainability of these resources (Widodo et al., 2001).

The area of shrimping in the Arafura Sea covered not only offshore but also inshore areas, which was nursery site of shrimps. Those fishing activities using net with mesh sizes that were not wide enough for small-size shrimps, including juveniles, to escape could result in growth overfishing. Growth overfishing in the shrimp fishery happens when shrimps caught before they have time to realise their growth potential, this occurs when fishing effort is higher and size of shrimp harvested is smaller than levels of effort and size of shrimps that produce maximum sustainable yield (MSY) or maximum yield-per-recruit in a fishery (Pauly, 1994; Caillouet et al., 2008). The non-targeted catches in the form of juveniles are disadvantageous, as this would reduce future yield and possible subsequent recruitment to the fishery. When the shrimps are caught before the cohort has had the opportunity to achieve its optimum biomass level, the fishery will lose much of the potential yield that could be achieved by catching them in the near future (Najmudeen \& Sathiadhas, 2008). Results of the study in India conducted by Najmudeen \& Sathiadhas, (2008) show that the current profit to the fishery from harvesting juvenile shrimps is smaller than forgone future profit from gaining larger size and higher price if the juveniles are not caught so having chance to grow before captured. However, Najmudeen \& Sathiadhas, (2008) do not present the minimum size of a cohort resulting in optimum profit to fishery.
The objective of this paper is to develop a bioeconomic analysis of shrimp fishery in the Arafura Sea facilitating the evaluation of impact of harvesting different size of shrimps on the performance of fishery. The model then is used to evaluate at-first-capturesize of shrimps and fishing mortality level that result in optimum profit. The evaluation is also undertaken at different natural mortality levels.

\section{MATERIALS AND METHODS}

A bioeconomic approach was used in the analysis, covering bio-physical and economic aspects, of the Arafura shrimp fishery. The method in the bio-physical analysis, that was used to estimate the catch weight, catch rate, mean individual weight of the shrimps in the catch and the biomass for each level of annual fishing efforts, is based on a yield analysis introduced and used by Thompson \& Bell, (1934). The lengthbased Thompson \& Bell model (Sanders, 1995; Sparre \& Venema, 1998) was used in this paper. A spreadsheet was used in the calculation. The step of calculation was very similar to the steps described by Sanders $(1993,1995)$. The difference is the use of a fixed fish price by Sanders (1993, 1995), while in this paper price varies with shrimp size. The equations used in the analyses that can be categorised as biophysical and economic components are presented in Table 1.

The majority of the input parameters used in this paper are from Naamin, (1984) and Purwanto, (2008, 2011). These input parameters are presented in Table 2. Other input parameters that are not available consist of annual natural mortality coefficient, recruit number at zero age, and shrimp price at different length classes. Therefore, these parameters were estimated in this study. 
Table 1. Variables \& parameters of the equations used in the analysis

\begin{tabular}{|c|c|c|c|}
\hline Variables \& parameters & Symbols & Equations & $\begin{array}{c}\text { Equation } \\
\text { number }\end{array}$ \\
\hline $\begin{array}{l}\text { Bio-physical component: } \\
\text { Start length }(\mathrm{cm}) \text { at } k \\
\text { End length }(\mathrm{cm}) \text { at } k \\
\text { Start age (year) at } k \\
\text { End age (year) at } k \\
\text { Mean individual weight (gm) at } k \\
\\
\text { Fishing mortality coefficient at } k \\
\text { Natural mortality coefficient at } k \\
\text { End population no. (million) at } k \\
\text { Mean population no. (million) at } k \\
\text { Catch no. (million) at class } k \\
\text { Natural death no. (million) at } k \\
\text { Catch weight (t) at } k \\
\text { Number of shrimps per kg at } k \\
\text { Total catch no. (million) } \\
\text { Total catch weight (t) } \\
\text { Catch rate (kg/vessel) } \\
\text { Mean individual weight (gm) }\end{array}$ & $\begin{array}{c}\mathrm{L}_{1} \\
\mathrm{~L}_{2} \\
\mathrm{t}_{1} \\
\mathrm{t}_{2} \\
\mathrm{w} \\
\mathrm{F} \\
\mathrm{M} \\
\mathrm{N}_{2} \\
\mathrm{~N} \\
\mathrm{Cn} \\
\mathrm{D} \\
\mathrm{Cw} \\
\mathrm{n} \\
\mathrm{Cn} \\
\mathrm{CW} \\
\mathrm{CR} \\
\mathrm{w}^{\prime}\end{array}$ & 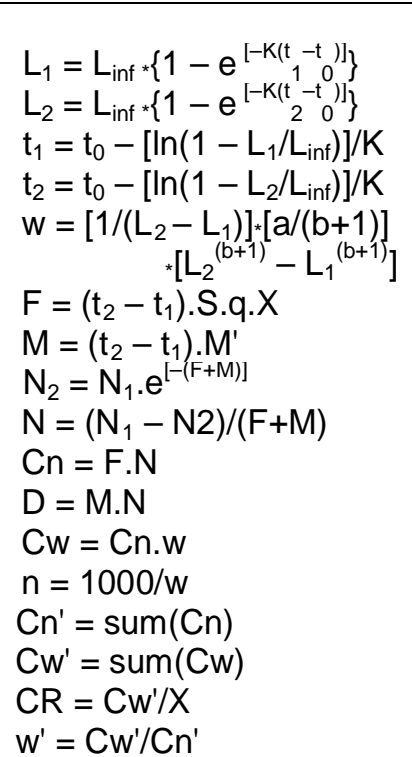 & $\begin{array}{l}(1) \\
(2) \\
(3) \\
(4) \\
\\
(5) \\
(6) \\
(7) \\
(8) \\
(9) \\
(10) \\
(11) \\
(12) \\
(13) \\
(14) \\
(15) \\
(16) \\
(17)\end{array}$ \\
\hline $\begin{array}{l}\text { Economic component: } \\
\text { Shrimp price (US\$ 1000/ton) } \\
\text { Catch value (USD 1000) } \\
\text { Gross revenue } \\
\text { Fishery cost } \\
\text { Fishery profit }\end{array}$ & $\begin{array}{l}\mathrm{Pr} \\
\mathrm{Gr} \\
\mathrm{GR} \\
\mathrm{FC} \\
\mathrm{PR}\end{array}$ & $\begin{array}{l}\mathrm{Pr}=u \cdot e^{(v \cdot n)} \\
\mathrm{Gr}=\mathrm{Cw} \cdot . \mathrm{Pr} \\
\mathrm{GR}=\operatorname{sum}(\mathrm{Gr}) \\
\mathrm{FC}=\mathrm{X} \cdot \mathrm{C} \\
\mathrm{PR}=\mathrm{GR}-\mathrm{FC}\end{array}$ & $\begin{array}{l}(18) \\
(19) \\
(20) \\
(21) \\
(22)\end{array}$ \\
\hline
\end{tabular}

Remarks:

$k=$ length class of shrimp size $(\mathrm{cm})$;

$\mathrm{S} \quad=$ selection ogive at length class $k$;

M' = annual natural mortality;

$\mathrm{N}_{1} \quad=$ start population number (million) at length class $k$

$\mathrm{X}=$ annual fishing effort (no. of vessels);

Equations (1) - (12), (14) - (17) and (19) - (22) are from Sanders (1993, 1995).

Table 2. The value of input parameters used in the analysis

\begin{tabular}{lccl}
\hline Input parameters & Symbols & Values & Sources \\
\hline Asymptotic length $(\mathrm{cm})$ & $\mathrm{L}_{\text {inf }}$ & 5.02 & Naamin $(1984)$ \\
Curvature coefficient $\left(\mathrm{yr} \mathrm{r}^{-1}\right)$ & $\mathrm{K}$ & 1.625 & Naamin $(1984)$ \\
Age at zero length $(\mathrm{yr})$ & $\mathrm{to}$ & -0.083 & Naamin $(1984)$ \\
Length at recruitment $(\mathrm{cm})$ & $\mathrm{Lr}$ & 1.60 & Sumiono (pers. comm.) \\
Length at first capture $(\mathrm{cm})$ & $\mathrm{Lc}$ & 2.45 & Naamin $(1984)$ \\
Length-weight equation constants & $\mathrm{a}$ & 0.646 & Naamin $(1984)$ recalculated \\
& $\mathrm{b}$ & 2.945 & Naamin $(1984)$ \\
Catchability coefficient & $\mathrm{q}$ & 0.001383 & Purwanto $(2008,2011)$ \\
Intrinsic growth rate & $\mathrm{r}$ & 1.7021 & Purwanto $(2008,2011)$ \\
maximum (virgin) population $\left(10^{3}\right.$ tonnes) & $\mathrm{B}_{\text {inf }}$ & 107.8 & Purwanto $(2008,2011)$ \\
Annual fishing effort (no. of vessels) & $\mathrm{X}$ & 421 & Purwanto $(2011)$ \\
total fishing costs (US $\left.\$ 10^{3} / \mathrm{vessel}^{\mathrm{y}} \mathrm{yr}\right)$ & $\mathrm{C}$ & 303.7 & Purwanto $(2008,2011)$ \\
\hline
\end{tabular}

The coefficient of annual natural mortality (M') was estimated by using an equation formulated by Pauly's empirical formula (Sparre \& Venema, 1998) as follows: 


$$
\begin{aligned}
\operatorname{Ln} M^{\prime}= & -0.0152-0.279, \ln \mathrm{L}_{\text {inf }}+0.6543, \ln \mathrm{K}+ \\
& 0.463 . \ln \mathrm{T}
\end{aligned}
$$

Where $T$ is the annual mean habitat temperature $\left({ }^{\circ} \mathrm{C}\right)$ of the water in which the shrimp stock lives. The $\mathrm{T}$ in the Arafura Sea was about $28^{\circ} \mathrm{C}$ (Sumiono, pers. comm.).

The annual recruitment was assumed to be constant. Therefore, the estimates of yields, etc. are equilibrium values. The recruit number of shrimp stock at zero age $(R)$ was estimated on the basis of yield $(\mathrm{Y})$ and yield per recruit $(\mathrm{Y} / \mathrm{R})$ as follows:

$$
R=Y /(Y / R)
$$

Yield of shrimps can be estimated by using a fishery production model (Anderson \& Seijo, 2010) as follows:

$$
\mathrm{Y}=\mathrm{F}^{\prime} \mathrm{B}
$$

Where:

$$
\begin{aligned}
F^{\prime} & =q \cdot X \\
B & =B_{\text {inf }}^{*}\left(1-F^{\prime} / r\right) \\
F^{\prime} & =\text { annual fishing mortality; } \\
Q^{\prime} & =\text { catchability coefficient; } \\
B_{\text {inf }} & =\text { maximum population which the living space } \\
& \text { and food supply support; } \\
r \quad & =\text { intrinsic growth rate. }
\end{aligned}
$$

Meanwhile, yield per recruit can be estimated by using a model developed by Beverton \& Holt (1957). A length-based version of the yield per recruit model (Sparre \& Venema, 1998) was used in the analysis as follows:

$$
\begin{aligned}
& Y / R=F_{*} A_{*} W_{\text {inf }} *\left[1 / Z-3 U /(Z+K)+3 U^{2} /(Z+2 K)-\right. \\
& \left.\mathrm{U}^{3} /(\mathrm{Z}+3 \mathrm{~K})\right]
\end{aligned}
$$

Where:

$$
\begin{array}{ll}
\mathrm{A} & =\left[\left(\mathrm{L}_{\text {inf }}-\mathrm{L}_{\mathrm{c}}\right) /\left(\mathrm{L}_{\text {inf }}-\mathrm{L}_{\mathrm{r}}\right)\right]^{\mathrm{M} / \mathrm{K}} \\
\mathrm{W}_{\text {inf }} & =\mathrm{a} \cdot \mathrm{L}_{\mathrm{inf}} \\
\mathrm{U}^{\mathrm{a}} & =1-\mathrm{L}_{\mathrm{c}} / \mathrm{L}_{\text {inf }} \\
\mathrm{Z} & =\mathrm{M}^{\prime}+\mathrm{F}^{\prime} .
\end{array}
$$

The price of shrimps is a function of shrimp size (equation 18). The parameters of the price equation were estimated by ordinary least square using data from Indonesian Shrimp Fishery Association.

\section{RESULTS}

The annual natural mortality of the shrimp stock was estimated to be about 1.9566 . The recruitment of shrimp stock in Arafura Sea in 2008 was estimated to be about 9359 million individual shrimps. Meanwhile, the price of shrimps was statistically affected by the shrimp size. The relationship between price and size of shrimps was represented by the following equation:

$$
\operatorname{Pr}=11.2098 * e^{-0.0205^{*} n}
$$

The peformance of fishery harvesting shrimps with the shortest carapace length $(C L)$ of $16 \mathrm{~mm}$ in year 2008, when the number of fishing vessels was 421 units creating fishing mortality of about 0.58 , is presented in Table 3. The estimated number of shrimps harvested was about 1577 million, with the mean length and weight of $29 \mathrm{~mm} \mathrm{CL}$ and 20 grams respectively. Meanwhile, the estimated number of shrimps died caused by natural mortality was about 7780 million. The estimates of total catch weight and value were about 30.8 thousand tonnes and US $\$ 162$ million per year, respectively. As the cost of fishing was US\$ 128 million per year, the estimate of total profit was about US\$ 34 million per year (Tables 3 \& 4).

Comparing the estimates of fishery performance for a range of annual fishing mortality, as presented in Table 4, vessel productivity decreased with increasing fishing mortality. Similarly, shrimp size decreased, which in turn decreasing shrimp price, when fishing mortality increased. Profit per vessel also decreased with increasing fishing mortality even at the low level of shrimp stock utilisation (Fig. 1). Further increase in fishing mortality could result in economic loss.

Meanwhile, the total profit to the shrimp fishery in the Arafura Sea increased with increasing fishing mortality when the utilisation of shrimp stock was at the low level. The fishery resulted in the optimum profit (US\$ 44.5 million/yr) when fishing mortality was about 0.36 and the size at first capture of shrimps was 16 $\mathrm{mm} \mathrm{CL}$ (Table 4, Fig. 1). The estimated catch of shrimps at the optimum total profit was about 22.4 thousand tonnes/year with the mean length of $30 \mathrm{~mm}$ $\mathrm{CL}$ and weight of 21 grams. After achieving the optimum total profit, increases in fishing mortality decreased total profit. Further increase in the fishing mortality could also result in economic loss. 


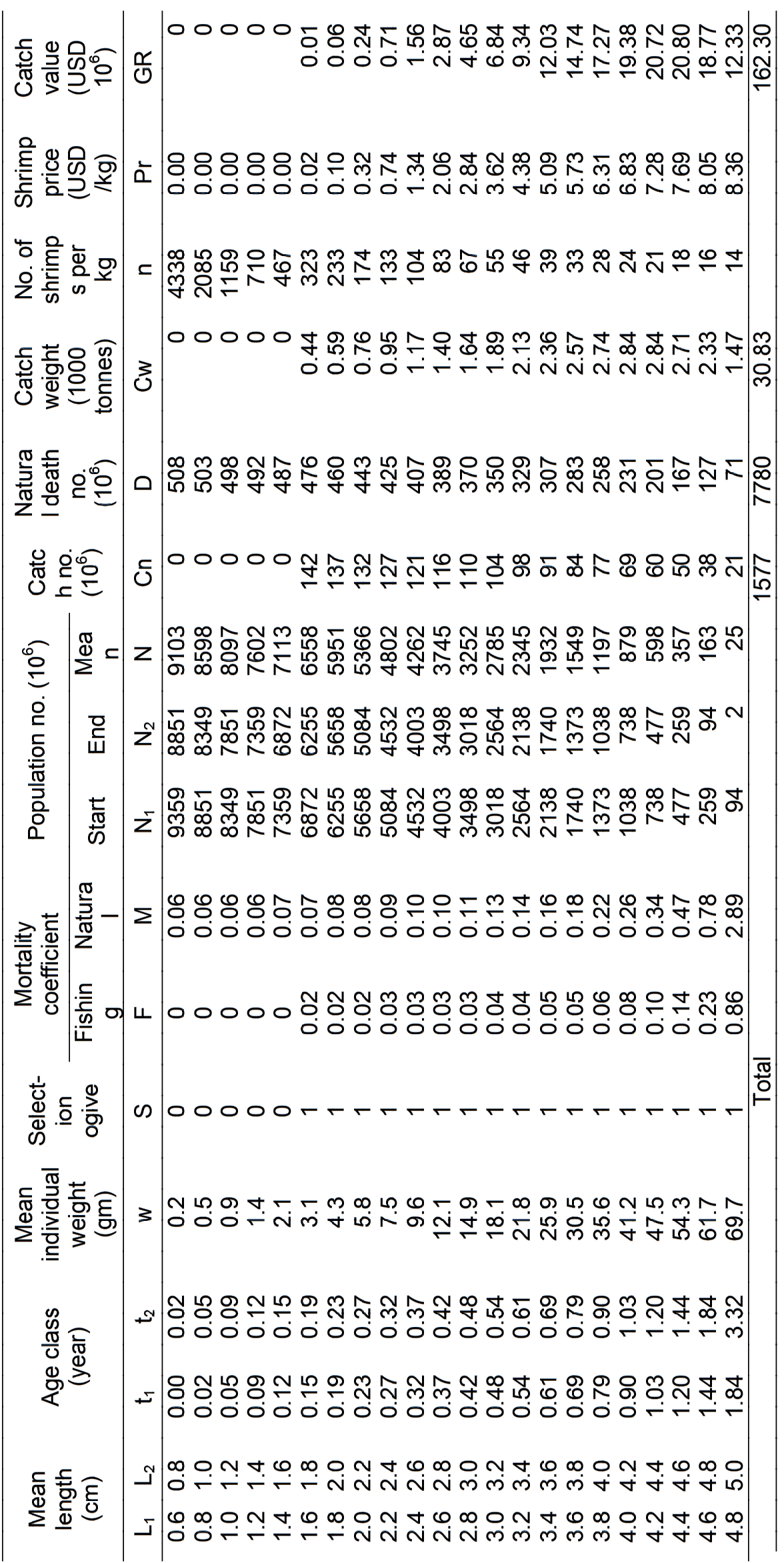


Table 4. Estimates of fishery performance for a range of annual fishing mortality

\begin{tabular}{cccccccc}
\hline $\begin{array}{c}\text { Fishing } \\
\text { mortality }\end{array}$ & $\begin{array}{c}\text { Catch } \\
\text { weight } \\
\left(10^{3} \mathrm{t} / \mathrm{yr}\right)\end{array}$ & $\begin{array}{c}\text { Catch rate } \\
(\mathrm{t} / \text { vessel } / \mathrm{yr})\end{array}$ & $\begin{array}{c}\text { Mean } \\
\text { caparace } \\
\text { length }(\mathrm{mm})\end{array}$ & $\begin{array}{c}\text { Mean } \\
\text { shrimp } \\
\text { weight } \\
(\mathrm{gm})\end{array}$ & $\begin{array}{c}\text { Gross } \\
\text { revenue } \\
(\mathrm{USD} \\
\left.10^{6} / \mathrm{yr}\right)\end{array}$ & $\begin{array}{c}\text { Fishery } \\
\text { cost } \\
(\mathrm{USD} \\
\left.10^{6} / \mathrm{yr}\right)\end{array}$ & $\begin{array}{c}\text { Fishery } \\
\text { profit (USD } \\
\left.10^{6} / \mathrm{yr}\right)\end{array}$ \\
\hline $\mathrm{F}$ & $\mathrm{Cw}^{\prime}$ & $\mathrm{Cw} / \mathrm{X}$ & $\mathrm{Cl}$ & $\mathrm{w}^{\prime}$ & $\mathrm{GR}$ & $\mathrm{FC}$ & $\mathrm{PR}$ \\
\hline 0.06 & 4.4 & 110.5 & 31.3 & 23.4 & 25.8 & 12.1 & 13.6 \\
0.11 & 8.4 & 105.4 & 31.0 & 23.0 & 48.6 & 24.3 & 24.3 \\
0.17 & 12.1 & 100.7 & 30.8 & 22.5 & 68.9 & 36.4 & 32.5 \\
0.22 & 15.4 & 96.2 & 30.6 & 22.1 & 86.9 & 48.6 & 38.3 \\
0.28 & 18.4 & 92.0 & 30.4 & 21.6 & 102.8 & 60.7 & 42.1 \\
0.33 & 21.1 & 88.1 & 30.2 & 21.2 & 116.8 & 72.9 & 43.9 \\
0.36 & 22.4 & 86.3 & 30.1 & 21.1 & 123.4 & 79.0 & 44.5 \\
0.39 & 23.6 & 84.4 & 30.0 & 20.8 & 129.2 & 85.0 & 44.2 \\
0.44 & 25.9 & 80.9 & 29.8 & 20.4 & 140.1 & 97.2 & 42.9 \\
0.50 & 28.0 & 77.7 & 29.6 & 20.1 & 149.6 & 109.3 & 40.3 \\
0.55 & 29.8 & 74.6 & 29.5 & 19.7 & 158.0 & 121.5 & 36.5 \\
0.58 & 30.8 & 73.2 & 29.4 & 19.6 & 162.2 & 127.9 & 34.4 \\
0.61 & 31.6 & 71.7 & 29.3 & 19.4 & 165.2 & 133.6 & 31.6 \\
0.66 & 33.1 & 69.0 & 29.1 & 19.0 & 171.5 & 145.8 & 25.7 \\
0.72 & 34.5 & 66.4 & 28.9 & 18.7 & 176.9 & 157.9 & 19.0 \\
0.77 & 35.8 & 64.0 & 28.8 & 18.4 & 181.5 & 170.1 & 11.5 \\
0.83 & 37.0 & 61.7 & 28.6 & 18.1 & 185.5 & 182.2 & 3.2 \\
0.89 & 38.1 & 59.5 & 28.4 & 17.8 & 188.7 & 194.4 & -5.6 \\
0.94 & 39.0 & 57.4 & 28.3 & 17.5 & 191.4 & 206.5 & -15.1 \\
\hline
\end{tabular}

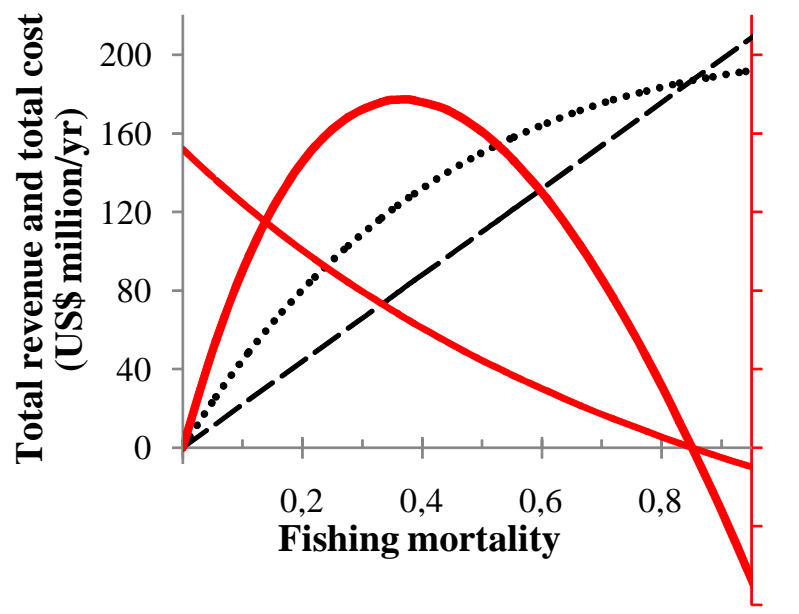

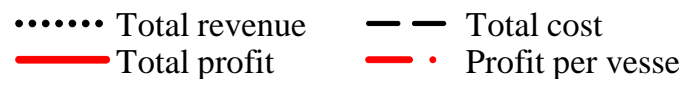

Figure 1. Total revenue, total cost and total profit to shrimp fishery in the Arafura Sea, when recruitment, length at first capture of shrimp stock and natural mortality were 9359 million recruits, $16 \mathrm{~mm} \mathrm{CL}$ and 1.96 respectively.
The impact of different minimum shrimp sizes, as indicated by the carapace length at first capture, on vessel productivity and production of shrimps from the Arafura fishery can be estimated and presented in Figure $2 \mathrm{a} \& \mathrm{~b}$, respectively. The relationships between vessel productivity and fishing effort at different sizes at first capture of shrimps were not different, the productivity declined with increasing fishing effort. Comparing productivity of vessels harvesting different first capture sizes at the fishing effort of year 2008, the highest productivity of fishing vessels was achieved when the smallest size of shrimps harvested was about $22 \mathrm{~mm} \mathrm{CL}$. Further, the highest shrimp production at the fishing mortality of year 2008 was also achieved when the shortest size of shrimps harvested was about $22 \mathrm{~mm}$ CL.

Similar to the vessel productivity, profit per vessel of shrimp fishery in the Arafura Sea also declined with increasing number of fishing vessels, but the amounts of per vessel profit were different depending on the first capture sizes of shrimps. Comparing the estimated profit gained by fishery from operating 421 vessels harvesting different first capture sizes, the 
highest profit per vessel (i.e. US\$ 131 thousand/yr) resulted from harvesting shrimps when the smallest size was about $28 \mathrm{~mm} \mathrm{CL}$ (Figure 3). When natural mortality decreased to 1.65 , the estimated profit per vessel increased to US $\$ 173$ thousand per year although the number of fishing vessels operated and the smallest size of shrimps harvested didnot change, namely 421 units and $28 \mathrm{~mm}$ respectively. If natural mortality increased to 2.45 , the estimated profit per vessel decreased to US $\$ 70$ thousand/yr when the number of fishing vessels operated and the smallest size of shrimps harvested didnot change.
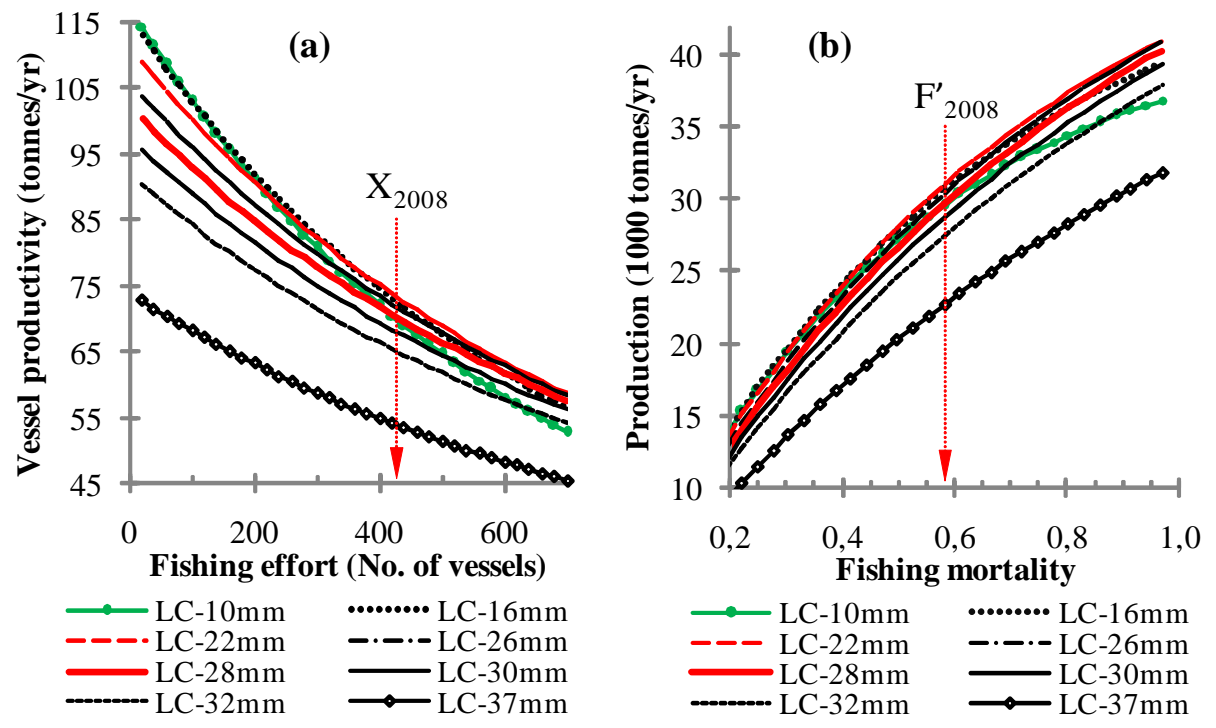

Figure 2. Impacts of different minimum shrimp sizes (LC-...) harvested by fishery in the Arafura Sea on: (a) the vessel productivity at different fishing effort levels, and (b) the production at different fishing mortality levels. (Remark: $\mathrm{X}_{2008} \& \mathrm{~F}_{2008}^{\prime}=$ level of fishing effort \& fishing mortality in year 2008).
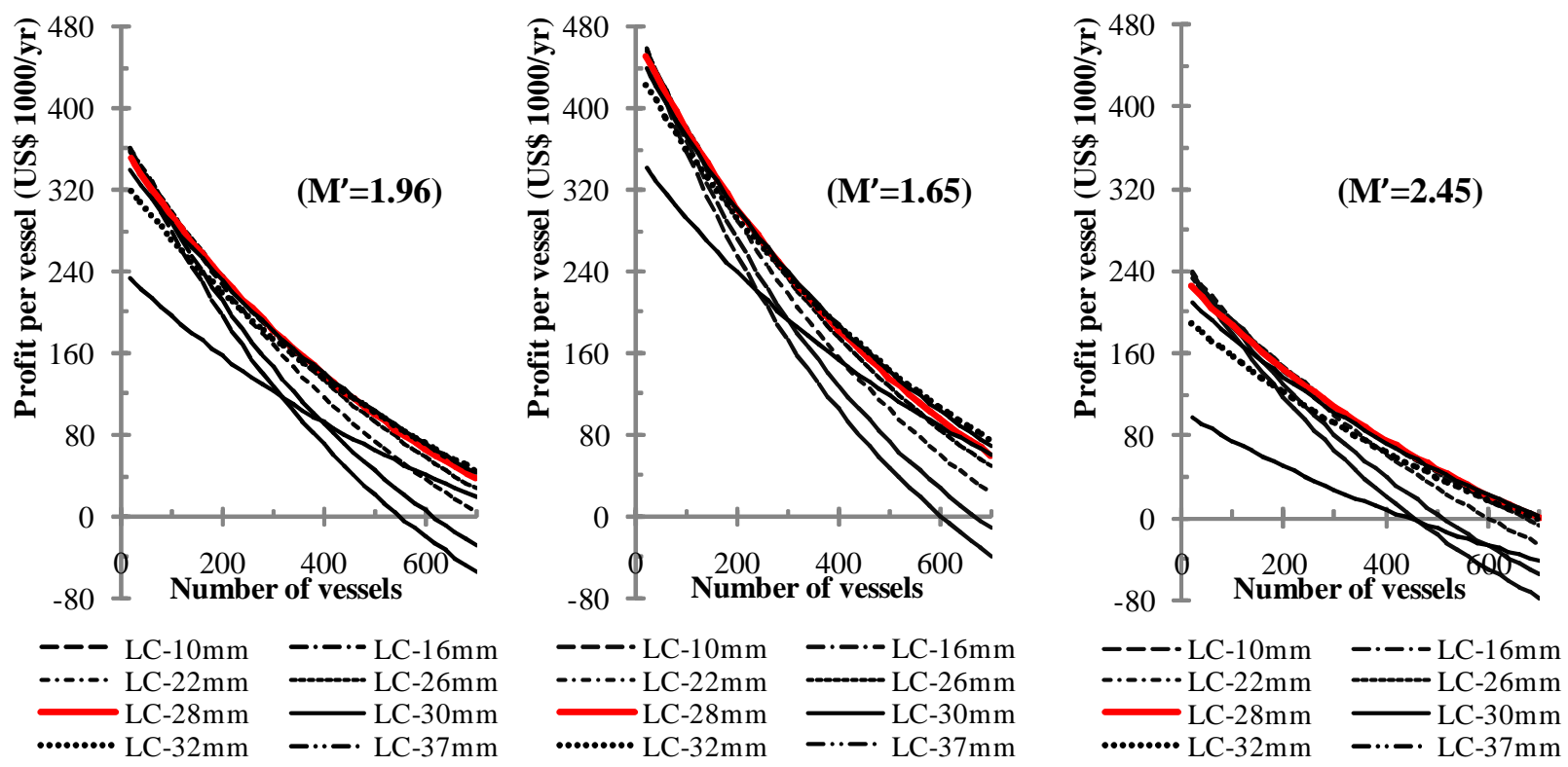

Figure 3. Impacts of different minimum shrimp (LC-...) sizes harvested by fishery in the Arafura Sea on the profit per vessel at different fishing effort levels (number of vessels), when natural mortality $\left(M^{\prime}=\ldots\right)$ was $1.96,1.65$, and 2.45 . 
As presented in Figure 1, there was an optimal fishing mortality, i.e. a certain level of fishing mortality that resulted in the optimum total profits. The optimal fishing mortality of shrimp fishery in the Arafura Sea varied with the first-capture sizes of shrimps. When natural mortality was 1.96 , the fishery would result in the optimum total profit, amounting to about US\$56.3 million/yr, if the first-capture size of shrimps was 29 $\mathrm{mm} \mathrm{CL}$ harvested at fishing mortality 0.50 (Figure 4).

At the first-capture size of shrimps of $29 \mathrm{~mm} \mathrm{CL}$ and fishing mortality 0.50 , decreasing natural mortality from 1.96 to 1.65 resulted in higher total profit, amounting to US\$74.0 million/yr. When natural mortality decreased, it was more economical to harvest shrimps at the larger size. At natural mortality 1.65 , the optimum total profit would be about US\$ $74.7 \mathrm{million} / \mathrm{yr}$ when the smallest size of shrimps caught and fishing mortality were $30 \mathrm{~mm}$ and 0.55 respectively (Figure 4). On the contrary, it was more economical to harvest shrimps at the smaller size when natural mortality increased. If natural mortality increased to 2.45 , the optimum total profit would be about US\$ 32.5 million/yr when fishery harvested shrimps at the first-capture size of $26 \mathrm{~mm} \mathrm{CL}$ and fishing mortality 0.41 (Figure 4).

\section{DISCUSSION}

This paper demonstrates the impact of harvesting different minimum sizes of shrimps at various fishing and natural mortalities on the performance of a fishery in the Arafura Sea. Fishing is basically an economic activity, that is conducted to gain profits. The optimal total profit to fishery resulted from harvesting a certain first-capture size of shrimps at a certain fishing mortality. As the estimates of recruitment and natural mortality in 2008 were 9359 million recruits and 1.96 respectively, the optimum total profit would be achieved if the first-capture size of shrimps and fishing mortality were $29 \mathrm{~mm} \mathrm{CL}$ and 0.50 respectively. The total profit to the fishery would be sub-optimal when the size of shrimps at first-capture was smaller than that optimal size. Similarly, the total profit was also sub-optimal when the size of shrimps at first-capture was larger than that optimal size.

The size at first capture and the smallest size of shrimps caught by shrimp trawlers in the Arafura Sea in 1982 were 24.5 and $21.5 \mathrm{~mm} \mathrm{CL}$, respectively (Naamin, 1984). Meanwhile Sumiono and Hargiyanto (pers. comm), from their observation in 2011, informed that the smallest size of shrimps harvested by trawlers in the Arafura Sea were 16-17 mm CL. Further, fishing pressures to the shrimp stock in the Arafura Sea resulted not only from the operation of trawlers but also from the operation of small scale fishery in coastal areas harvesting juvenile and pre-adult cohorts. These data and information indicated the possibility of the first capture size of shrimps harvested from the Arafura Sea in 2011 to be smaller than that in 1982. These also indicated that shrimp fishery in the Arafura Sea was economically in a sub-optimal condition. From an economic point of view, the fishing activity targeting shrimp stock should be controlled to ensure that fishery gains optimum profit. Furthermore, from a biological point of view, it would be beneficial to the sustainability of stock when a cohort of shrimps has chance to grow to the optimal size and to produce offsprings before harvested. Therefore, effort should also be undertaken to make sure that the size at first capture is larger than the size at maturity. The optimum first capture size estimated in this study $(29 \mathrm{~mm} \mathrm{CL})$ is larger than the estimate of the size at maturity, i.e about $25.9 \mathrm{~mm}$ CL (Naamin, 1984). Therefore, a fishery management policy that controls fishing activity to harvest shrimps at the first capture size of $29 \mathrm{~mm} \mathrm{CL}$ and the fishing mortality of 0.50 would ensure the optimum level of shrimp fishery.

This study also demonstrated that variation in the natural mortality resulted in different optimum levels of first capture size of shrimps and total profit to the fishery. When natural mortality decreased, it was more economical to harvest shrimps at the larger size and higher fishing mortality, accommodating more vessels, and resulting in higher total profit. On the contrary, it was more economical to harvest shrimps at the smaller size when natural mortality increased (Fig. 4). In the last condition, the fishery could accommodate fewer vessels and gain lower total profit. The natural mortality is caused by all other factors than fishing, for example predation, diseases, spawning stress, starvation, and old age The rate of natural mortality rate, caused by predation and starvation for example, are linked to the ambient ecosystem (Sparre \& Venema, 1998). The ecosystem, therefore, should be maintained, in conjunction with controlling fishing activity, to sustain shrimp stock and to optimise fishery profit. Further, improvement of the ecosystem would result in higher benefits. Mangroves in the coastal areas are the important part of the ecosystem functioning as nursery site of shrimps. Staples \& Vance (1986), Pauly \& Ingles (1986), Baran \& Hambrey (1998) and Loneragan et al. (2005) reported the positive correlation between the size of mangrove areas and the quantity of shrimps harvested by commercial fishery. 

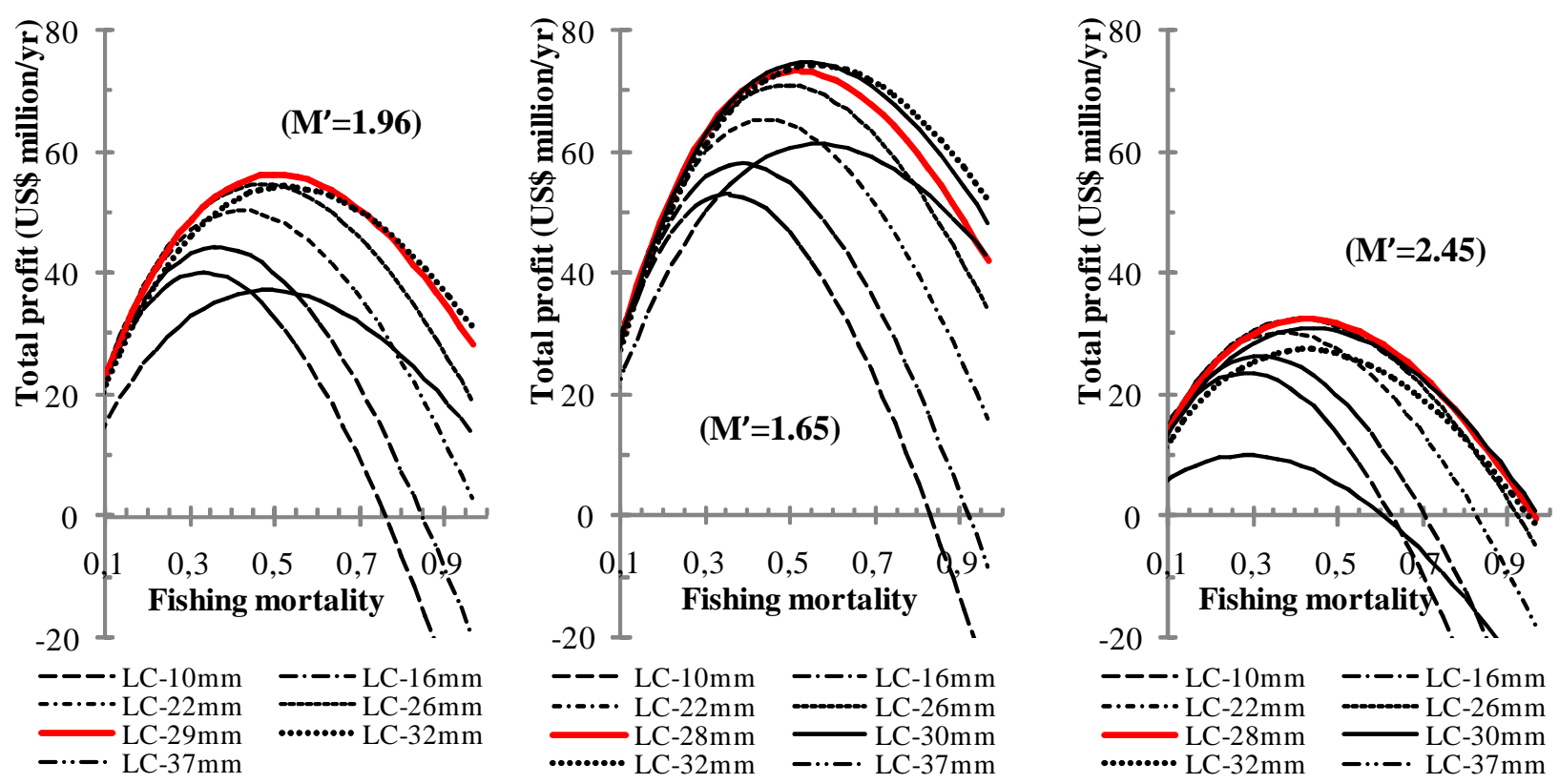

Figure 4. Impacts of different minimum shrimp sizes (LC-...) harvested by fishery in the Arafura Sea on the total profit gained at different fishing mortality levels, when natural mortality $\left(\mathrm{M}^{\prime}=\ldots\right)$ was $1.96,1.65$ and 2.45 .

\section{CONCLUSION}

1. The optimal total profit to fishery resulted from harvesting a certain first-capture size of shrimps at a certain fishing mortality. The total profit to the fishery would be sub-optimal when the size of shrimps at first-capture was smaller or larger than the optimal size;

2. In the bio-economic condition of year 2008, the fishery achieved the optimal total profit when the size of shrimps at first-capture and fishing mortality were $29 \mathrm{~mm} \mathrm{CL}$ and 0.50 respectively;

3. The variation in the natural mortality resulted in different optimum levels of first capture size of shrimps and total profit to the fishery. When natural mortality decreased, it was more economical to harvest shrimps at the larger size and higher fishing mortality, accommodating more vessels, and resulting in higher total profit. On the contrary, it was more economical to harvest shrimps at the smaller size when natural mortality increased.

\section{REFERENCES}

Anderson, L.G. \& J.C. Seijo. 2010. Bioeconomics of Fisheries Management. Wiley-Blackwell, Ames. $305 \mathrm{p}$.
Badrudin, B. Sumiono \& N. Wirdaningsih. 2002. Laju tangkap, hasil tangkapan maksimum (MSY), dan upaya optimum perikanan udang di Laut Arafura. J. Penelitian Perikanan Indonesia, 8 (4): 23-29.

Bailey, C., A. Dwiponggo, \& F. Marahudin. 1987. Indonesian marine capture fisheries. ICLARM Studies and Reviews 10.

Baars, M.A., A.B. Sutomo, S.S. Oosterhuis, \& O.H. Arinardi. 1990. Zooplankton abundance in the eastern Banda Sea and northern arafura sea during and after the upwelling season, August 1984 and February 1985. Netherlands Journal of Sea Research, 25 (4): 527-543.

Baran, E., \& J. Hambrey, 1998. Mangrove Conservation and Coastal Management in Southeast Asia: What Impact on Fishery Resources? Marine Pollution Bulletin. 37 (8-12): 431-440.

Cadee, G.C. 1988. Organic carbon in the upper 100 $\mathrm{m}$ and downward flux in the Banda Sea; monsoonal differences. Netherlands Journal of Sea Research. 22 (2): I09-121.

Caillouet Jr., C.W., R.A. Hart, \& J.M. Nance, 2008. Growth overfishing in the brown shrimp fishery of Texas, Louisiana, and adjoining Gulf of Mexico EEZ. Fisheries Research. 92: 289-302. 
Loneragan, N.R., N. Ahmad Adnan, R.M. Connolly, \& F.J. Manson, 2005. Prawn landings and their relationship with the extent of mangroves and shallow waters in western peninsular Malaysia. Estuarine, Coastal and Shelf Science. 63: 187200.

Naamin, N. 1984. Dinamika populasi udang jerbung (Penaeus merguiensis de Man) di perairan Arafura dan alternatif pengelolaannya. Disertasi Doktor. Fakultas Pasca Sarjana. institut Pertanian Bogor. $281 \mathrm{p}$.

Nagelkerken, I., S.J.M. Blaber, S. Bouillon, P. Green, M. Haywood, L.G. Kirton, J.-O. Meynecke, J. Pawlik, H.M. Penrose, A. Sasekumar, \& P.J. Somerfield. 2008. The habitat function of mangroves for terrestrial and marine fauna: A review. Aquatic Botany. 89: 155-185.

Najmudeen, T.M., \& R. Sathiadhas, 2008. Economic impact of juvenile fishing in a tropical multi-gear multi-species fishery. Fisheries Research. 92: 322332.

Pauly, D. 1994. From growth to malthusian overfishing: Stages of fisheries resources misuse. SPC Traditional Marine Resource Management and Knowledge Information Bulletin. 3: 7-14.

Pauly, D., \& J. Ingles, 1986. The relationship between shrimp yields and intertidal vegetation (mangrove) area: a reassessment. In: Yanez-Arancibia, A., Pauly, D. (Eds.), IOC/FAO Workshop on Recruitment in Tropical Coastal Demersal Communities. UNESCO, Paris, p. 277-284.

Primavera, J. H., 1997. Fish predation on mangroveassociated penaeids: The role of structures and substrate. Journal of Experimental Marine Biology and Ecology, 215: 205-216.

Primavera, J. H., 1998. Mangroves as Nurseries: Shrimp Populations in Mangrove and Nonmangrove Habitats. Estuarine, Coastal and Shelf Science, 46: 457-464.

Purwanto. 2008. Resource rent generated in the Arafura shrimp fishery. Final Draft. Prepared for the World Bank PROFISH Program. Washington. D.C. 29 p.

Purwanto. 2011. A compromise solution to the conflicting objectives in the management of the Arafura shrimp fishery. Ind. Fish. Res. J., 17 (1): 37-44.
Robertson, A.I. \& N. C. Duke, 1987. Mangroves as nursery sites: comparisons of the abundance and species composition of fish and crustaceans in mangroves and other nearshore habitats in tropical Australia. Marine Biology 96: 193-205.

Sadhotomo, B., P. Rahardjo \& Wedjadmiko. 2003. Pengkajian kelimpahan dan distribusi sumberdaya demersal dan udang di perairan Laut Arafura. Prosiding Forum Pengkajian Stok Ikan Laut 2003. Pusat Riset Perikanan Tangkap, Departemen Kelautan dan Perikanan, Jakarta.

Sanders, M.J. 1993. Fishery performance and the value of future entitlements under quota management: A case study of a handline fishery in the southwest Indian Ocean. Fish. Res., 18: 219-229.

Sanders, M.J. 1995. Introduction to Thompson and Bell yield analysis using Excel spreadsheets. FAO Fisheries Circular, no. 895. Rome, FAO. 21p.

Sparre, P. \& S.C. Venema. 1998. Introduction to tropical fish stock assessment. Part 1. Manual. FAO Fisheries Technical Paper, no. 306.1, Rev. 2. Rome, FAO. 407p.

Staples, J., \& D. J. Vance, 1986. Emigration of juvenile banana prawns Penaeus merguiensis from a mangrove estuary and recruitment to offshore areas in the wet-dry tropics of the Gulf of Carpentaria, Australia. Mar. Ecol. Prog. Ser., 27: 239-252.

Tijssen, S.B., M. Mulder, \& EJ. Wetsteyn. 1990. Production and consumption rates of oxygen, and vertical oxygen structure in the upper $300 \mathrm{~m}$ in the eastern Banda Sea during and after the upwelling season, August 1984 and February/March 1985. Netherlands Journal of Sea Research, 25 (4): 485499.

Thompson, W.F. \& F.W., Bell, 1934. Biological statistics of the Pacific halibut fishery. 2. Effect of changes in intensity upon total yield and yield per unit of gear. Rep. Int. Fish. (Pacific Halibut) Comm., 8: 49pp.

Vance, D. J., M. D. E. Haywood \& D. J. Staples, 1990. Use of a Mangrove Estuary as a Nursery Area by Postlarval and Juvenile Banana Prawns, Penaeus merguiensis de Man, in Northern Australia. Estuarine, Coastal and Shelf Science, 31:689-701. 
Vance, D. J., M. D. E. Haywood, D. S. Heales, R. A. Kenyon, N. R. Loneragan, \& R. C. Pendrey. 1996. How far do prawns and fish move into mangroves? Distribution of juvenile banana prawns Penaeus merguiensis and fish in a tropical mangrove forest in northern Australia. Mar. Ecol. Prog. Ser., 131: 115-124.

Vance, D. J., M. D. E. Haywood, D. S. Heales, R. A. Kenyon, N. R. Loneragan, \& R. C. Pendrey. 2002. Distribution of juvenile penaeid prawns in mangrove forests in a tropical Australian estuary, with particular reference to Penaeus merguiensis. Mar. Ecol. Prog. Ser., 228: 165-177.

Wetsteyn, F.J., A.G. Ilahude, \& M.A. Baars. 1990. Nutrient distribution in the upper $300 \mathrm{~m}$ of the eastern Banda Sea and northern Arafura Sea during and after the upwelling season, August 1984 and February 1985. Netherlands Journal of Sea Research, 25(4): 449-464.

Widodo, J., Purwanto \& S. Nurhakim. 2001. Evaluasi Penangkapan Ikan di Perairan ZEEI Arafura: Pengkajian sumberdaya ikan demersal. Direktorat Jenderal Perikanan, Departemen Kelautan dan Perikanan. Jakarta.

Wyrtki, K. 1961. Physical Oceanography of the Southeast Asian Waters. NAGA Rep., 2: 195 pp.

Keputusan Menteri Kelautan dan Perikanan nomor 45/Men/2011 tentang Estimasi Potensi Sumberdaya Ikan di Wilayah Pengelolaan Perikanan Negara Republik Indonesia. 